Liv Gjestrum, universitetslektor, liv.gjestrum@oslomet.no; Kim Tallerås, førsteamanuensis, kim.talleras@oslomet.no; Åse Kristine Tveit, førsteamanuensis, aase.k.tveit@oslomet.no. Institutt for arkiv- bibliotek- og informasjonsfag, OsloMet - storbyuniversitetet, Norge

\title{
"Vi søker deg med relevant høyere utdanning": Kompetansebehov i det bibliotekfaglige profesjonsfeltet
}

\begin{abstract}
It is claimed that today's professions are challenged and that they may disappear, either because more tasks are automated, or somewhat less dramatically - because the professions have to redefine their roles, due to technological changes and other reasons. Such changes also challenges institutions that educate professional practitioners. As academic staff, teaching students in library and information science, we need to know what competencies are requested in our professional fields. We have collected and examined job advertisements from the most important national channels, from 2015-18, where workplace is a library institution, or where librarian expertise is specifically mentioned. We have analyzed competencies and educational backgrounds, and we have made comparisons to similar data from 2002. The theoretical perspective of the study is derived from the sociology of professions, and the material has been studied using statistical analysis in combination with qualitative content analysis. The study shows that the fields of practice are looking for significantly different professional skills, depending on the type of institution and position in question. Relevant ICT skills and skills in communication are emphasized in almost all advertisements. The analysis also reveals that today more often than in 2002, candidates with a degree other than in library and information science are targeted for positions in libraries.
\end{abstract}

Keywords: Stillingsannonser, arbeidsmarked, kompetanse, bibliotekarer, utdanning, profesjonsteori

\section{Introduksjon}

To think about the future of librarianship, then, is not to dream about riding up an escalator to the structural trappings of professionhood. Rather, it is to think about the likely evolution of librarians' work and to ask what the consequences of that evolution might be for the occupation (Abbott, 1998).

Det hevdes fra flere hold at dagens profesjoner utfordres og at de etter hvert kan forsvinne helt, enten fordi profesjonenes arbeidsoppgaver automatiseres, eller noe mindre dramatisk - fordi profesjonene må redefinere 
sine roller av både informasjonsteknologiske og andre grunner (Jochumsen, 2017; Séguinot, 2007; Susskind \& Susskind, 2015; Wilkinson, Hislop \& Coupland, 2016). Slike endringer er også utfordrende for institusjonene som utdanner profesjonsutøvere. Som ansatte ved Institutt for arkiv-, bibliotek- og informasjonsfag ved OsloMet storbyuniversitetet (heretter OsloMet, tidligere $\mathrm{H} \emptyset$ gskolen i Oslo og Akershus) trenger vi kunnskap om hvilke kompetanser våre profesjonsfelt etterspør, i planlegging og utvikling av fagporteføljen. I denne artikkelen presenterer vi resultatene fra en undersøkelse hvor formålet er å kartlegge hvilke kompetanser som er etterspurt i bibliotekarenes arbeidsmarked. Undersøkelsen baserer seg på analyser av innsamlede stillingsannonser fra 2002 og 2015-2018, og søker å besvare følgende spørsmål:

- Hvilke kompetansebehov kommer til uttrykk i stillingsannonser som springer ut av det bibliotekfaglige profesjonsfeltet?

- Hvilke formelle utdanningskrav etterspørres i stillingsannonsene?

- Hvilken utvikling i kompetansebehov- og utdanningskrav kan spores fra 2002 til i dag?

Artikkelen innledes med noen begrepsavklaringer, og etterfølges av en redegjørelse for det profesjonsteoretiske perspektiv som er anlagt. Relevant forskning på feltet presenteres, før vi redegjør for metoden som er brukt. I den påfølgende analysedelen presenteres kompetansebehov og utdanningskrav i samtidige stillingsannonser. I tillegg trekkes sammenligninger til stillingsannonsene fra 2002, for å se hvilke forandringer i arbeidsmarkedet vi kan se over de siste femten årene. Den avsluttende diskusjonen løfter fram våre funn og drøfter disse opp mot tidligere forskning.

Stillingsannonsene vi har analysert, bruker ulike betegnelser på det arbeidsgiverne etterspør hos søkerne: kompetanse, kvalifikasjoner, kunnskaper, ferdigheter, arbeidsoppgaver og arbeidsområder. Av og til angir altså arbeidsgiver hva han/hun ønsker at søkerne skal beherske, av og til hvilke arbeidsoppgaver/arbeidsområder den nytilsatte skal ha ansvar for. "Formidling" og "katalogisering" kan for eksempel både vise til type kunnskaper og praktiske gjøremål. Begrepet kompetanse har vært omtalt i profesjonssosiologien fra 1930-tallet. Fauske (2008, s. 41-42) omtaler diskusjonen mellom sosiologene Parson og Hutchins, hvor sistnevnte er bekymret for at profesjonsutdanningene vil være mer opptatt av praktisk nytte enn kunnskap for kunnskapens egen skyld. Parson er opptatt av profesjonenes samfunnsmessige betydning, men mener at profesjonenes kompetanse ikke bare kan bestå av praktiske ferdigheter, men at den også må være forankret i akademisk kunnskap.

Også innen utdanningsområdet er kompetanse et sentralt begrep, og store internasjonale organisasjoner som OECD, EU (Bolognaprosessen) $\mathrm{m}$. fl. anvender begrepet, men ofte med ulikt eller upresist innhold (Illeris, 2011). I den norske stortingsmeldingen "Kultur for læring" (Kultur- og forskningsdepartementet, 2004), defineres kompetanse som "Evnen til å møte komplekse utfordringer. (...) Kompetanse er forstått med hva man gjør og får til i møtet med utfordringer" (s. 31). Kompetansebegrepet omfatter ifølge de fleste definisjoner holdninger i tillegg til kunnskaper og ferdigheter. Jørgensen $(1999$, s. 4) uttrykker det slik:

[...] at personen kan anvende den faglige viden - og mere end det: anvende den i forhold til de krav, der ligger i en situasjon, der måske oven i købet er usikker og uforudsigelig. Dermed indgår i kompetence også personens vurderinger og holdninger - og evne til at trække på en betydelig del av sine mer personlige forudsætninger. Udtrykt kort kan man sige, at kompetence set fra et individsynspunkt, omfatter et kvalifikationsaspekt, et handleaspekt og et personlig aspekt.

I denne artikkelen brukes begrepet "kompetanse" som en samlebetegnelse for de arbeidsoppgaver, arbeidsområder, kvalifikasjoner, kunnskaper og ferdigheter som arbeidsgiver etterspør.

\section{Teoretiske perspektiver på profesjonsutvikling}

I boka The future of the professions (2015) skisserer Richard og Daniel Susskind store utfordringer for profesjonene. De uttrykker seg spissformulert, og hevder at teknologiutviklingen vil bety slutten for profesjonene slik vi kjenner dem i dag. Ifølge forfatterne har profesjonene fire felles hovedtrekk: Spesialistkunnskap, 
adgangsregulering ved utdanningskrav, (lov)regulerte aktiviteter og et felles verdigrunnlag. Dette er trekk vi delvis kan gjenkjenne fra bibliotekarprofesjonen, i Norge blant annet gjennom Bibliotekloven (1985) som krever fagutdannede bibliotekledere, og ved en etablert bibliotekfaglig spesialistutdanning.

Profesjonene utviklet sine spesialistkunnskaper for å møte industrisamfunnets behov. I dagens digitale samfunn krakelerer profesjonene fordi "the professions in their current form will no longer be the best answer to those needs" (Susskind og Susskind, 2015, s. 3). Forfatterne presenterer to mulige framtidsperspektiver, begge relatert til teknologiutviklingen. En mulighet er en mer effektivisert versjon av dagens situasjon, der profesjonene bruker ny teknologi for å optimalisere sine arbeidsoperasjoner. Alternativt vil systemer og maskiner, som opererer med eller uten menneskelig nærvær, komme til å ta over hoveddelen av arbeidsoppgavene som i dag utføres av tradisjonelle profesjoner. I denne studien undersøker vi blant annet om det er mulig å etterspore en slik utvikling når det gjelder arbeidsmarkedet for bibliotekarer, slik det framkommer i stillingsannonser.

Sosiologen Andrew Abbott er i boka The System of professions (1988) opptatt av profesjonenes jurisdiksjon. Jurisdiksjon innebærer i denne sammenhengen hvilke arbeidsoppgaver en profesjon har eksklusive rettigheter til å ut $\varnothing$ ve; oppgaver den har kontroll over. Jurisdiksjon kan bli fremmet gjennom lover, i det offentlige rom (public opinion) eller gjennom praksis på arbeidsplassen. Jurisdiksjon uttrykt gjennom lover er naturlig nok den sterkeste. "Bibliotekar" er ikke en beskyttet yrkestittel i Norge, og med unntak av ledere i folkebibliotek, er det ikke et lovpålagt krav om bibliotekfaglig utdanning for å bli tilsatt som bibliotekar. I praksis har imidlertid bibliotekarene tilkjempet seg jurisdiksjon til bibliotekariske arbeidsoppgaver, og bibliotek- og informasjonsfaglig utdanning har i de fleste tilfelle vært inngangsbilletten ved ansettelse i bibliotek. Ett unntak er fagreferentene ved universitetsbibliotekene hvor akademikere med relevant fagbakgrunn har blitt foretrukket fremfor kandidater med bibliotekarutdanning.

Professor i bibliotek- og informasjonsvitenskap, Jan Nolin beskriver i In search of a new theory of professions (2008) utviklingen innen profesjonsteorien. Han deler utviklingen inn i tre faser: Professions (1930 - 1970), Professionalisation (1960-1980) og Social context (1980 - ). Mens forskerne i første fase er opptatt av profesjoner som «instruments of enlightenment and a key function in modernisation of society» (s. 11), har fase to (hvor Abbott er en vesentlig bidragsyter) fokus på rivaliseringen mellom profesjonene og kampen for eneretten til arbeidsoppgavene. Fase tre består ifølge Nolin av ulike teoretiske tilnærminger, og kjennetegnes ikke av noen bestemt tendens. Nolin mener at Abbotts innfallsvinkel til profesjonsteorien med fokus på kampen for jurisdiksjon og på egennytte, er lite fruktbar. Abbotts tilnærming til studiet av profesjonene kan altså fortolkes slik at den legger lite vekt på profesjonenes ønske om å utvikle bedre tjenester og å tjene samfunnet. Selv foreslår Nolin en fjerde tilnærming. I stedet for å studere profesjonene med et kritisk utenfrablikk, bør forskerne samarbeide med profesjonsut $\varnothing$ verne for å finne teoretiske instrumenter som kan hjelpe dem i yrkesut $\varnothing$ velsen.

\section{Tidligere forskning}

Det er ikke forsket særskilt på norske stillingsannonser på bibliotekområdet tidligere. Det foreligger noe forskning på det norske arbeidsmarkedet for bibliotekarutdannede, basert på data fra såkalte kandidatundersøkelser foretatt av utdanningsinstitusjonene hvor studentenes karriere følges opp med kontinuerlige spørreundersøkelser over tid. Når det gjelder internasjonal forskning på stillingsannonser, avgrenses unders $\varnothing$ kelsene gjerne til gitte stillingstyper, for eksempel Digital librarian (Choi \& Rasmussen, 2009), Preservation professionals (Miller \& Horan, 2017) eller Metadata professionals (Park \& Lu, 2009). Det avgrenses også ofte til gitte typer arbeidsområder, for eksempel Digital curation (Kim, Warga \& Moen, 2013). Disse studiene er dermed ikke helt sammenlignbare med vår generelle unders $\emptyset$ kelse, men vi har latt oss inspirere av metoder som baserer seg på statistiske undersøkelser av for eksempel utdanningskrav og kompetanser. Det finnes også noen generelle studier. Noen av disse ligger et stykke tilbake i tid (for eksempel Kennan, Willard, \& Wilson, 2006), mens andre er mer sammenlignbare. Wise, Henninger og Kennan (2011) har sammenlignet annonser fra 2004 og 2010. Deres utvalg baserer seg på match i annonser mot utvalgte kjernekompetanser og ikke på utdanningsbakgrunn eller institusjonstype. De dekker dermed et bredere arbeidsmarked enn vår studie. Et interessant funn i den australske unders $\varnothing$ kelsen fra 2011, er at typiske kjernekompetanser innenfor tradisjonell 
bibliotek- og informasjonsvitenskap, som kunnskaper om informasjonsadferd og informasjonsbehov, nok kan ha et potensiale i Web- og systemutviklingsbransjer, men de er ikke særlig etterspurt i bibliotekene. De finner ellers en bredde i arbeidsmarkedet med mange etterspurte kompetanser. Når det gjelder bibliotekene, hevder studien at kompetansene til den tidligere etterspurte "breddebibliotekaren" har blitt en forventet grunnpakke, og at det i større grad etterlyses spesialisert kompetanse i tillegg.

I artikkelen "Bibliotekarer bli ved din lest" (2015) har Bøyum, Dahl og Pharo undersøkt arbeidsmarkedet for studenter i bibliotek- og informasjonsvitenskap uteksaminert fra Høgskolen i Oslo og Akershus i perioden 20112014. Tallmaterialet baserer seg på data fra Kandidatundersøkelsen som ble gjennomført ved HiOA i 2015. De har blant annet unders $\varnothing$ kt hvor studentene har fått jobb, stillingstittel og arbeidsoppgaver. Som tittelen på artikkelen angir, fant de fleste arbeid i bibliotek, hele $83,2 \%$, hvorav $56 \%$ i folke-, fylkes- eller skolebibliotek, og $28,2 \%$ i fag- og forskningsbibliotek. Kandidatene ble bedt om å angi hva de anså som sine viktigste arbeidsoppgaver, og de kunne velge blant 16 forhåndsdefinerte oppgaver eller spesifisere dem selv. For ansatte i folke-, skole- og fylkesbibliotek kom litteraturformidling på første, samlingsutvikling på andre og referansearbeid på tredjeplass. De som jobbet i fag- og forskningsbibliotek, oppga opplæring og veiledning som den viktigste og referansearbeid som den nest viktigste. Klassifikasjon og katalogisering (som utgjorde én kategori) og samlingsutvikling ble ansett å være tredje viktigst. Vi brukte ikke de forhåndsdefinerte kategoriene utviklet av $B \varnothing y u m$ et al. i våre egne analyser, men trekker inn resultatene fra denne unders $\varnothing$ kelsen i diskusjonen av våre egne funn.

\section{Metode}

Datautvalg

Målsetningen med datainnsamlingen var å samle inn et representativt utvalg av norske annonser knyttet til arbeidsmarkedet for bibliotekarer. I Norge finnes to viktige kilder til jobbannonser, NAV (den norske Arbeids- og velferdsforvaltningen) og Finn.no (kommersiell markedsplass på nett). Tjenestene er i stor grad overlappende, men ikke helt. For å sikre at vi fikk med så mange relevante annonser som mulig, har vi hentet annonser fra begge tjenester. I tillegg har vi lett etter annonser i alternative kilder som e-postlisten "Bibliotek-Norge". For å sikre et konsistent og representativt utvalg inkluderte vi jobbannonser ut fra følgende kriterier: Det skal eksplisitt fremkomme av annonsen at stillingen gjennom stillingsbetegnelse, utlysningstekst eller utdanningskrav enten er myntet på bibliotekarer, ELLER at den er plassert i en bibliotek-institusjon.

Stillinger som mer eller mindre åpenbart «kan passe» for en bibliotekar utenfor en bibliotek-institusjon, men hvor betegnelsene bibliotekar, bibliotek eller bibliotekarutdanning ikke brukes eksplisitt, utelates dermed selv om de er aktuelle. Tidligere unders $\varnothing$ kelser av arbeidsmarkedet for bibliotekarer viser for eksempel at mange kandidater med utdannelse på masternivå befant seg i et arbeidsmarked utenfor bibliotekinstitusjonene, både i privat næringsliv og innenfor offentlig forvaltning og administrasjon (Dahl \& Tallerås, 2011). Vi kjenner også til at mange bibliotekarer jobber innenfor mediebransjen, for eksempel med research opp mot journalistikken, med dokumentasjon i privat næringsliv eller innenfor kulturforvaltningen. Ettersom slike stillinger rekrutterer personer med ulik bakgrunn, oppgis ofte ikke utdanning eksplisitt. Det hadde vært interessant å studere denne delen av arbeidsmarkedet, men det ville være svært vanskelig å fange opp aktuelle stillinger og skape et representativt utvalg som kunne behandles statistisk.

Samlingen av annonser fra 2002 har vi fått fra NAV. Gjengivelsen av disse annonsene viste seg å være av ulik kvalitet, og mange av annonsene manglet store deler av utlysningstekstene. I denne studien har vi derfor plukket ut et tilfeldig utvalg annonser som inneholdt nok informasjon til at de kunne analyseres. For at de skulle kunne brukes i en sammenligning med dagens annonser, sørget vi for at fordelingen på type bibliotek gjenspeilet den vi fant i de nyere annonsene. Utvalgene inneholder dermed omtrent en like stor andel folkebibliotek, universitets- og høgskolebibliotek (UH-bibliotek) osv. 
Fra desember 2015 til januar 2018 har vi samlet inn 222 annonser som møtte våre kriterier. Vi har tatt for oss utlysningstekster noen måneder for hvert av disse årene (for 2018 inkluderte vi kun januar). Materialet vårt omfatter derfor ikke det totale antall utlyste stillinger for denne perioden. Fra 2002 har vi valgt ut 47 annonser.

\section{Registrering}

Etter innsamlingen ble annonsene registrert av de tre forfatterne i et skjema med en rekke variabler. Før registreringen startet, gjennomførte vi en test som dannet grunnlaget for de kategoriene som forekom oftest. I tillegg til å bruke disse hadde den som registrerte mulighet til å legge til nye kategorier i et "annet"-felt. Nye kategorier ble tilføyd den etablerte listen kontinuerlig. På denne måten fanget vi opp flest mulig nyanser i annonsene. Selv om mange av kategoriene i den påfølgende analysen ble fortolket som synonymer eller nestensynonymer, og slått sammen, ga bredden i de opprinnelige dataene blant annet anledning til å fange opp arbeidsmarkedets egen begrepsbruk. Ved å overlate fortolkningen til analysearbeidet sikret framgangsmåten også en konsistent registrering.

Artikkelforfatterene kommer fra tre ulike områder av bibliotek- og informasjonsvitenskapen (slik disse er inndelt ved OsloMet); kunnskapsorganisasjon og gjenfinning, informasjon og samfunn og litteratur- og kulturformidling. Registreringen og det påfølgende analysearbeidet er dermed basert på betraktninger og enighet på tvers av ulike fagtradisjoner og perspektiv. Særlig nyttig var disse ulike perspektivene $\mathrm{i}$ sammenstillingen av kompetanseområder beskrevet nedenfor. Her ble 200 kompetanseuttrykk analysert og gruppert. Forfatterne grupperte først individuelt $f \varnothing r$ de individuelle resultatene ble presentert, grundig diskutert og sammenstilt i fellesskap gjennom en konsensusprosess. Disse grupperingene ble videre belyst og bekreftet gjennom videre statistiske unders $\varnothing$ kelser.

\section{Analyse}

Analysen av annonsene er først og fremst basert på en statistisk studie av de registrerte dataene. I første del av denne analyseseksjonen presenterer vi noen utvalgte variabler fra 2015-18-materialet som beskriver de annonserte stillingene på et generelt nivå. I annen del ser vi disse variablene i sammenheng når vi beskriver trekk ved 15 særskilte kompetanseområder som peker seg ut i materialet. I siste del undersøker vi tallene fra 2002.

\section{Type stilling}

Ettersom vi ikke har avgrenset utvalget av annonser til en bestemt type institusjon eller stillingsbetegnelse, inngår en rekke ulike typer stillinger i materialet. Tabell 1 viser fordelingen av institusjoner $\mathrm{i}$ antall og prosent for annonsene i perioden 2015-18.

\begin{tabular}{|l|r|r|}
\hline Folkebibliotek & 107 & $48 \%$ \\
\hline Universitet- eller høgskolebibliotek & 53 & $24 \%$ \\
\hline Skolebibliotek & 32 & $14 \%$ \\
\hline Fagbibliotek & 16 & $7 \%$ \\
\hline Annet & 10 & $5 \%$ \\
\hline Arkiv & 4 & $2 \%$ \\
\hline Totalt & 222 & $100 \%$ \\
\hline
\end{tabular}

Tabell 1. Annonser fra 2015-2018 fordelt på institusjonstype. 
Nesten halvparten av de utlyste stillingene i materialet kommer fra folkebibliotek. Nest størst er gruppen med stillinger fra UH-bibliotek. Deretter følger skolebibliotekene som her teller bibliotek både på videregående - og grunnskolenivå. Vi har valgt å skille ut fagbibliotek som befinner seg utenfor utdanningssektoren $\mathrm{i}$ en egen kategori. Noen av dem etterspør personer som skal drive med dokumentasjonsarbeid i næringslivet, andre er mer typiske forskningsbibliotek. I kategorien Annet finner vi utlyste stillinger for eksempel som medarbeider i en kommunal kulturetat hvor bibliotekarutdanning nevnes som en relevant fagbakgrunn.

$34 \%$ av stillingene er utlyst fra arbeidsplasser i landets fire største byer. De resterende stillingene er godt spredt utover landet. $55 \%$ er faste heltidsstillinger, $18 \%$ er faste deltidsstillinger og $27 \%$ er midlertidige (vikariater og engasjementer).

Det er stor variasjon i stillingsbetegnelsene. $60 \%$ bruker betegnelsen bibliotekar, men gjerne i kombinasjon med en tilleggsbetegnelse. UH-bibliotekene søker typisk en "spesial- eller universitetsbibliotekar", men også "IT-" eller "metadata"-bibliotekarer. Mange folkebibliotek søker en "bibliotekar/litteraturformidler". I tillegg til bibliotekarstillingene finner vi $12 \%$ lederstillinger av typen "biblioteksjef" eller "bibliotekleder", og $8 \%$ som bruker begrepet "bibliotek-". Mest typisk blant disse er "bibliotekmedarbeider". De øvrige betegnelsene (ca. $20 \%$ ) varierer fra "researcher" til "aktivitetskoordinator".

\section{Utdanningskrav}

I annonsene uttrykkes de samme utdanningskravene på svært ulike måter. Vi utviklet derfor kategorier som gjenspeiler hva som faktisk kreves av utdanning. Tabell 2 viser en liste over disse kategoriene og fordelingene i antall og prosent. 


\begin{tabular}{|c|c|c|c|c|}
\hline \multicolumn{3}{|c|}{ Utdanningskrav } & \multicolumn{2}{|c|}{$2015-2018$} \\
\hline & & & Antall & Prosent \\
\hline \multirow{7}{*}{$\begin{array}{l}\text { Utdanning hvor } \\
\text { bibliotek og } \\
\text { informasjonsfag er } \\
\text { nevnt i } \\
\text { utlysningen (79\%) }\end{array}$} & \multicolumn{2}{|c|}{ Krav om (minimum) bachelor i bibliotek- og informasjonsfag } & 81 & $36 \%$ \\
\hline & \multicolumn{2}{|c|}{ Krav om master i bibliotek- og informasjonsfag } & 1 & $0 \%$ \\
\hline & \multicolumn{2}{|c|}{$\begin{array}{l}\text { Krav om høyere utdanning på bachelor eller masternivå med } \\
\text { bibliotek- og informasjonsfag i fagkretsen }\end{array}$} & 13 & $6 \%$ \\
\hline & $\begin{array}{l}\text { Krav om (minimum) bachelor i } \\
\text { bibliotek- og informasjonsfag, } \\
\text { eller... }\end{array}$ & $\begin{array}{l}\text {...annen relevant høyere } \\
\text { utdanning }\end{array}$ & 71 & $32 \%$ \\
\hline & & $\begin{array}{l}\text {...relevant } \\
\text { realkompetanse }\end{array}$ & 3 & $1 \%$ \\
\hline & & $\begin{array}{l}\text {....relevant } \\
\text { masterutdanning }\end{array}$ & 2 & $1 \%$ \\
\hline & $\begin{array}{l}\text { Krav om master i bibliotek- og } \\
\text { informasjonsfag, eller... }\end{array}$ & $\begin{array}{l}\text {...relevant } \\
\text { masterutdanning }\end{array}$ & 3 & $1 \%$ \\
\hline \multirow{3}{*}{$\begin{array}{l}\text { Utdanning hvor } \\
\text { bibliotek og } \\
\text { informasjonsfag } \\
\text { ikke nevnt i } \\
\text { utlysningen (21\%) }\end{array}$} & \multicolumn{2}{|c|}{ Krav om uspesifisert høyere utdanning } & 18 & $8 \%$ \\
\hline & \multicolumn{2}{|c|}{ Krav om spesifisert høyere utdanning } & 18 & $8 \%$ \\
\hline & \multicolumn{2}{|l|}{ Ingen utdanningskrav } & 12 & $5 \%$ \\
\hline \multicolumn{3}{|l|}{ Totalt } & 222 & $100 \%$ \\
\hline
\end{tabular}

Tabell 2. Utdanningskrav uttrykt i annonsene 2015-2018

79\% av annonsene nevner bibliotek og informasjonsfag i utlysningen. Den største gruppa, 36\%, krever (minimum) bachelorgrad i bibliotek- og informasjonsvitenskap. En typisk formulering lyder: "Godkjent bibliotekarutdanning (3-årig bachelorgrad i bibliotek- og informasjonsfag)". Den nest største gruppa, 32\%, er de som ønsker bachelorgrad i bibliotek- og informasjonsvitenskap eller en annen relevant utdanning. En typisk formulering i denne kategorien er: "Bibliotekfaglig utdanning, minimum 3-årig utdanning innenfor bibliotek- og informasjonsfag, eller annen faglig relevant utdanning". Mange utlysninger av denne typen nevner spesifikke alternative fagfelt. Spesielt hyppig forekommer litteraturfag (nevnt i 20 annonser, og kulturfag (15). Utdanninger innenfor IKT, arkiv eller pedagogikk forekommer også i en del annonser.

Masterutdanning i bibliotek- og informasjonsfag nevnes sjelden. En av grunnene kan være at det finnes et begrenset antall kandidater i Norge med denne utdannelsen, og derfor vil noen arbeidsgivere kvie seg for å avgrense $s \varnothing$ keadgangen eksklusivt til denne gruppen. Langt de fleste med mastergrad har dessuten bachelorgrad innenfor fagområdet, og kan dermed søke på jobber i de to største kategoriene. 
Av 23 stillinger utlyst i folkebibliotek i landets 4 største byer krever kun én minimum bachelor i bibliotek- og informasjonsfag. 13 nevner bibliotek- og informasjonsfag, men åpner opp for annet relevant utdanning. Samlet sett krever $64 \%$ av utlysningene ikke direkte bibliotekfaglig utdanning.

\section{Kompetanser og arbeidsoppgaver}

Som nevnt i introduksjonen lister gjerne stillingsannonsene opp aktuelle arbeidsoppgaver og -områder og angir relevante kunnskaper og kvalifikasjoner, og ofte skilles det ikke klart mellom disse. Ettersom det har vist seg vanskelig å skille disse aspektene kategorisk fra hverandre, opererer vi i den følgende analysen med en kompetanse-variabel som dekker litt ulike aspekter, slik de språklig er uttrykt i annonsene. Registreringsprosessen tok som nevnt utgangspunkt i en test-registrering av kompetanseuttrykk og en liste med etablerte verdier fra denne. Dette sikret både en konsistent og fleksibel kategoriseringprosess. Vi endte til slutt opp med 200 uttrykk for ulike kompetanser.

Tabell 3 viser en liste over uttrykk som finnes i minst ti annonser.

\begin{tabular}{|c|c|}
\hline Digital kompetanse & 127 \\
\hline God skriftlig- og muntlig framstillingsevne & 108 \\
\hline Publikumsbetjening & 104 \\
\hline Formidling & 69 \\
\hline Engelskkunnskaper & 61 \\
\hline Arrangement & 56 \\
\hline Løpende oppgaver & 54 \\
\hline Veiledning & 51 \\
\hline Samlingsutvikling & 50 \\
\hline Prosjekt- og utviklingsoppgaver & 45 \\
\hline Utviklingsarbeid & 44 \\
\hline Samarbeid barnehage/skole & 37 \\
\hline Litteraturformidling & 36 \\
\hline Undervisning & 36 \\
\hline Ledelse & 31 \\
\hline Ansvar for daglig drift & 26 \\
\hline Brukeropplæring & 26 \\
\hline $\begin{array}{l}\text { Kontaktperson (med andre avdelinger/andre fagmiljøer/andre } \\
\text { virksomheter/kommunale tilbud) }\end{array}$ & 25 \\
\hline Nettverk lokalt nasjonalt og internasjonalt & 23 \\
\hline
\end{tabular}




\begin{tabular}{|c|c|}
\hline Faglig lederansvar & 21 \\
\hline Katalogisering & 21 \\
\hline Administrativt ansvar & 21 \\
\hline Sosiale medier & 20 \\
\hline Personalansvar & 19 \\
\hline$\varnothing$ konomisk ansvar & 19 \\
\hline Forskningsst $\varnothing$ tte & 18 \\
\hline Lesestimulering & 16 \\
\hline Litteraturkunnskap & 14 \\
\hline Møteplassfunksjon & 13 \\
\hline Biblioteksystem & 13 \\
\hline Barne- og ungdomslitteraturkunnskap & 12 \\
\hline Rådgivning & 11 \\
\hline Biblioteksystemet Micromarc & 11 \\
\hline Systemutvikling & 11 \\
\hline Utstillinger & 11 \\
\hline Barne- og ungdomsarbeid & 11 \\
\hline Digitalisering & 10 \\
\hline Kildebruk og kildekritikk & 10 \\
\hline Informasjonskompetanse & 10 \\
\hline Biblioteksystemene Alma og Oria & 10 \\
\hline Budsjettarbeid & 10 \\
\hline Læringsarena & 10 \\
\hline Litteraturveiledning & 10 \\
\hline
\end{tabular}

Tabell 3. Kompetanser og arbeidsoppgaver uttrykt i annonsene 2015-2018.

De fire uttrykkene på topp i lista inngår i nesten halvparten av annonsene. De er nokså generelle, men de er ikke uten faktisk innhold. Mange av uttrykkene er nært beslektede, og noen kan betraktes som under-kategorier av andre uttrykk (for eksempel Litteraturformidling-Formidling). De uttrykker like fullt meningsinnhold på ulike abstraksjonsnivå. Når en annonse nevner formidling men ikke litteratur, kan formidling innebære andre eller mer generelle aspekter, og vi har valgt å beholde de ulike uttrykkene. 
Lista over kompetanser må kunne sies å tegne et svært bredt bilde av hva en og samme bibliotekar kan forventes å kunne. Vi kan si at denne bredden er i ferd med å sprenge forestillingen om en avgrenset profesjon, slik Abbott og også Susskind og Susskind definerer den. Det er nokså langt fra det å bedrive litteraturformidling i et folkebibliotek til å tilby forskningsstøtte fra et spesialisert fagbibliotek, og fra kunnskap om navngitte informasjonssystemer til bibliotekets rolle som møteplass og debattarena. I den lange halen av kompetanseuttrykk som ikke er inkludert i tabell 3, som inneholder uttrykk som betegner enda mer spesialisert kompetanse, blir denne bredden enda tydeligere. Her inngår alt fra å håndtere klassebesøk til journalføring i arkiv- og saksbehandlingssystem.

\section{Kompetanseområder}

Lista i tabell 3 viser kun kompetanser og arbeidsområder som forekommer i mer enn 10 annonser. Lista er allerede nokså lang, og til sammen fant vi altså 200 ulike uttrykk. Disse har vi gruppert i 15 "kompetanseområder". Områdene beskrives i oversikten nedenfor. Ett uttrykk tilhører ett kompetanseområde, men én annonse kan naturlig nok inneholde uttrykk fra flere områder. Grupperingen tok utgangspunkt i en konsensusprosess blant forfatterne beskrevet i metodeseksjonen. Videre unders $\varnothing$ kte vi $\varnothing$ vrige data for hvert kompetanseområde for å se om utdanningskrav og institusjonstyper bekreftet grupperingene. I den siste delen av analysen isolerte vi alle annonser som inneholdt uttrykk inkludert i gitte kompetanseområder og sammenlignet gjennomsnitt for utvalgte variabler blant disse med gjennomsnittet for hele materialet. I tabell 4 nedenfor oppsummeres hvert område med en typisk stilling (stillingen(e) som inneholdt flest ulike termer fra kompetanseområdet), de fire mest typiske kompetanseuttrykkene, de mest relevante institusjonstypene og utdanningskravene. Det $b \varnothing r$ nevnes at alle kompetanseområder er representert $\mathrm{i}$ alle institusjonstyper og kategorier for utdanningskrav, men vi finner tydelige tendenser for hver gruppe. I tabellen har vi inkludert og fremhevet disse tendensene. Tallene i parentes beskriver hvor mange annonser som inneholder uttrykk fra kompetanseområdet og de enkelte uttrykk som sådan.

\begin{tabular}{|c|c|c|}
\hline $\begin{array}{l}\text { Administrasjon og } \\
\text { forskningsstøtte (36) } \\
\text { Typisk stilling: } \\
\text { Universitetsbibliotekar i } \\
\text { UH-bibliotek } \\
\text { Typiske kompetanser: } \\
\text { Forskningsstøtte (18), } \\
\text { Elektronisk publisering (6), } \\
\text { Institusjonelt arkiv (6), } \\
\text { Open Access (5) } \\
\text { Institusjonstyper: UH- } \\
\text { bibliotek, fagbibliotek } \\
\text { Utdanningskrav: } \\
\text { Spesifisert høyere } \\
\text { utdanning, i mindre grad } \\
\text { bibliotek- og } \\
\text { informasjonsvitenskap }\end{array}$ & $\begin{array}{l}\text { Kunnskapsorganisasjon (75) } \\
\text { Typisk stilling: Spesial- eller } \\
\text { universitetsbibliotekar i UH- } \\
\text { bibliotek } \\
\text { Typiske kompetanser: } \\
\text { Katalogisering (21)/Metadata } \\
\text { (8), Biblioteksystem (13), } \\
\text { Kildebruk og kildekritikk (10), } \\
\text { Litteratur- og } \\
\text { informasjonssøking (8) } \\
\text { Institusjonstyper: } \\
\text { Hovedsakelig UH-bibliotek, } \\
\text { men også noe folkebibliotek } \\
\text { Utdanningskrav: } \\
\text { Bibliotekfaglig utdanning }\end{array}$ & $\begin{array}{l}\text { Prosjekt- og utviklingsarbeid } \\
\text { (56) } \\
\text { Typisk stilling: Biblioteksjef, } \\
\text { folkebibliotek } \\
\text { Typiske kompetanser: Prosjekt- } \\
\text { og Utviklingsoppgaver (45), } \\
\text { Utviklingsarbeid (44), } \\
\text { Tjenesteutvikling (3) } \\
\text { Institusjonstyper: Folkebibliotek } \\
\text { Utdanningskrav: Bibliotekfaglig } \\
\text { eller annen relevant utdanning }\end{array}$ \\
\hline
\end{tabular}


Arkiv- og

dokumentasjonsarbeid

(17)

Typisk stilling: Rådgiver i

arkiv eller fagbibliotek

Typiske kompetanser:

Dokumentstyring (7),

Arkivarbeid (5), Håndtering

av arkiv- og

saksbehandlingssystem (4),

Journalføring (3)

Institusjonstyper:

Arkivinstitusjoner og

fagbibliotek

Utdanningskrav:

Spesifisert arkiv-utdanning ofte er bibliotek- og

informasjonsfag et alternativ

\section{Biblioteket som} møteplass, debatt- og

kunnskapsarena (69)

Typisk stilling: Bibliotekar i

folkebibliotek

Typiske kompetanser:

Arrangement (56),

Møteplassfunksjon (13),

Læringsarena (10),

Miljøskapende aktiviteter

(3)

Institusjonstyper:

Folkebibliotek,

skolebibliotek

Utdanningskrav:

Bibliotekfaglig eller annen relevant utdanning, ofte nevnt Litteratur- og kulturfag
Ledelse (74)

Typisk stilling: Biblioteksjef, folkebibliotek

Typiske kompetanser: Ledelse (31), Ansvar for daglig drift

(26), Faglig lederansvar (21),

Administrativt ansvar (21)

Institusjonstyper:

Folkebibliotek

Utdanningskrav:

Bibliotekfaglig utdanning, men også annen relevant eller spesifisert utdanning, ofte knyttet til kulturfag
Samlingsutvikling (57)

Typisk stilling: Spesialbibliotekar i et UH-bibliotek

Typiske kompetanser:

Samlingsutvikling (50), Innkjøp

(6), Leverandørkontrakt (2) og

Lisensavtaler (2)

Institusjonstyper: UH-bibliotek, Skolebibliotek, Folkebibliotek Utdanningskrav:

Utdanningskravet gjenspeiler mer eller mindre tallene for hele materialet
Spesialistkunnskap (47)

Typisk stilling: Barne- og

ungdomsbibliotekar,

Folkebibliotek

\section{Typiske kompetanser:}

Litteraturkunnskap (15), Barneog ungdomslitteraturkunnskap

(12), Mediakunnskap (5),

Offentlig forvaltning (2)

Institusjonstyper: Folkebibliotek Utdanningskrav: Bibliotekfaglig eller annen relevant utdanning 
Formidling (73)

Typisk stilling:

Avdelingsleder barn og

unge, folkebibliotek

Typiske kompetanser:

Fomidling (69),

Litteraturformidling (36),

Lesestimulering (16),

Utstillinger (11)

Institusjonstyper:

Folkebibliotek, men også

en del skolebibliotek.

Utdanningskrav:

Bibliotekfaglig eller annen

relevant utdanning.

Litteratur- og kulturfag

nevnes ofte som alternativ.
Nettverksbygging (92)

Typisk stilling:

Aktivitetskoordinator i

folkebibliotek

Typiske kompetanser:

Samarbeid barnehage/skole

(37), Kontaktperson med

andre fagmiljøer, virksomheter

eller kommunale tilbud (28),

Nettverk lokalt og

internasjonalt (23), Sosiale

medier (20)

Institusjonstyper:

Folkebibliotek

Utdanningskrav:

Bibliotekfaglig eller annen relevant utdanning. Litteraturog kulturfag nevnes ofte som alternativ.
IKT (48)

Typisk stilling:

Spesialbibliotekar i UHbibliotek, IT-bibliotekar i

folkebibliotek

Typiske kompetanser:

Digital kompetanse (127),

Digitalisering (10),

Systemutvikling (11), IKT-

drift (8)

Institusjonstyper: UH-

bibliotek, Folkebibliotek

Utdanningskrav:

Bibliotekfaglig eller annen

relevant utdanning, spesifisert IKT-utdanning

forekommer.

\section{Pedagogisk arbeid (94)}

Typisk stilling:

Spesialbibliotekar i et UH-

bibliotek, bibliotekar i et

skolebibliotek,

prosjektmederabeider $\mathrm{i}$

arkiv/fagbibliotek

Typiske kompetanser:

Veiledning (51), Undervisning

(36), Brukeropplæring (26)

Institusjonstyper: Overvekt

UH-bibliotek og skolebibliotek, men forekommer i de fleste

institusjonstypene

Utdanningskrav: Noe mer

bibliotekfaglig utdanning enn

for hele materialet, men ofte

åpenhet for relevante

alternativer, særlig pedagogikk
Språkkunnskap (62)

Typisk stilling: Spesialbibliotekar

i et UH-bibliotek

Typiske kompetanser:

Engelskkunnskaper (61)

Institusjonstyper: UH-bibliotek

Utdanningskrav: Bibliotekfaglig

utdanning, noe hyppigere

etterspørsel etter spesifisert

utdanning på andre områder.
Systemer og standarder (44)

Typisk stilling:

Bibliotekar/konsulent, UH-

bibliotek

Typiske kompetanser:

Micromarc (11), Alma og Oria

(10), Bibliofil (5), NOARK (4)

Institusjonstyper: UH-bibliotek

Utdanningskrav: Bibliotekfaglig

utdanning

Tabell 4. Kompetanseområder med typiske stillinger, kompetanseuttrykk, institusjoner og utdanningskrav (2015-18).

I vår opprinnelige gruppering inkluderte vi de tre vanligste kompetansene på hvert sitt område: Digital kompetanse i IKT-området, Publikumsbetjening blant Løpende oppgaver og God skriftlig og muntlig fremstillingsevne blant Språkkunnskapene. I analysen av områdene er de imidlertid utelatt. Kompetansene inngår i så mange av annonsene at disse mistet noe av sin analytiske kraft på grunn av redundans. Vi tok dem derfor ut for å kunne få et bedre inntrykk av det som virkelig særpreger de ulike kompetanseområdene. Dette innebærer at de aktuelle områdene er ganske mye større enn det som fremkommer av tallene i tabellen.

Selv om de ulike kompetanseområdene gjør seg gjeldende i nær alle institusjonstyper, gjør de det med til dels svært skjev fordeling. Folkebibliotek er for eksempel sterkt overrepresentert i Formidlings-området, og UHbibliotek har en betydelig overvekt når det gjelder kunnskapsorganisasjon. Arkiv og dokumentasjonsarbeid 
foregår, ikke uventet, nesten utelukkende i arkiv og fagbibliotek. Tall på fordeling innenfor institusjonstypene forsterker dermed våre vurderinger av de etablerte områdene. Uten at institusjonstypene utgjør naturlige ytterpunkter og motsatser på en lineær akse, er det slik i datamaterialet at kompetanseområdene kan plasseres $i$ et "rom" med fire hjørner konstituert av henholdsvis UH-bibliotek, fagbibliotek og arkiv, folkebibliotek og skolebibliotek. Figur 1 viser hvordan de ulike kompetanseområdene plasserer seg i et slikt rom.

Figuren viser også de mest typiske relasjonene mellom områdene, basert på i hvilken grad de har kompetanseuttrykk til felles. Disse relasjonene danner dermed et nettverk med områdene som noder. Et par av områdene synes å fungere som samlende hubber i nettverket med mange inngående relasjoner fra de øvrige områdene. Dette gjelder spesielt Pedagogikk og Nettverksbygging. Disse er da også plassert nokså sentralt i rommet. De øvrige områdene forsterker plasseringene av områdene ved å danne noen særskilte klynger med mange interne relasjoner og få ut til områder i de фvrige klyngene. Vi har for eksempel en tydelig klynge på UHsiden i rommet hvor Språkkunnskaper, Systemer og standarder, Kunnskapsorganisasjon, og delvis IKT og Pedagogikk inngår. På den andre siden av rommet, mot folkebibliotekene, finner vi en tydelig klynge med Formidling, Biblioteket som møteplass, debatt og kunnskapsarena, Spesialistkunnskap, Prosjekt og utviklingsarbeid og delvis Ledelse og løpende oppgaver. Samlingsutvikling og Nettverksbygging fungerer som hubber i midten. Arkiv- og dokumentasjonsarbeid er tydelig plassert i arkivinstitusjoner og fagbibliotek, men har naturlig nok de fleste av sine relasjoner knyttet til UH-klyngen. Skolebibliotekene har ingen slike tydelige kompetanseområder, men gjør seg gjeldende i flere, og da særlig Pedagogisk arbeid, Samlingsutvikling og Ledelse. De to hovedklyngene har få forbindelser utover de indirekte som går via Pedagogisk arbeid og Nettverksbygging.

Vi hadde i utgangspunktet ventet at området Spesialistkunnskap skulle være knyttet til fagbibliotekene og til de ulike spesialistkunnskapene som er nødvendige i en fagreferentstilling. Området inkluderer kompetanseuttrykk som eksplisitt bruker begrepet kunnskap (Litteraturkunnskap) eller som tydelig angir et fagområde (Offentlig forvaltning). Slik kunnskap ble med unntak av språk, som utgjør et eget tydelig område, plassert her. Kunnskapene peker $\mathrm{i}$ litt forskjellige retning, men inngår stort sett $\mathrm{i}$ annonser fra folkebibliotek og handler $\mathrm{i}$ overveiende grad om ulike former for litteraturkunnskap. Dette betyr ikke at vi mangler fagreferentstillinger $i$ materialet, men de er få og uttrykker spesialistkompetansen først og fremst gjennom utdanningskrav. Når det gjelder området Språkkunnskap, omfatter det hovedsakelig Engelskkunnskaper og er tydeligst etterspurt i fagbibliotek. 


\section{Skolebibliotek}

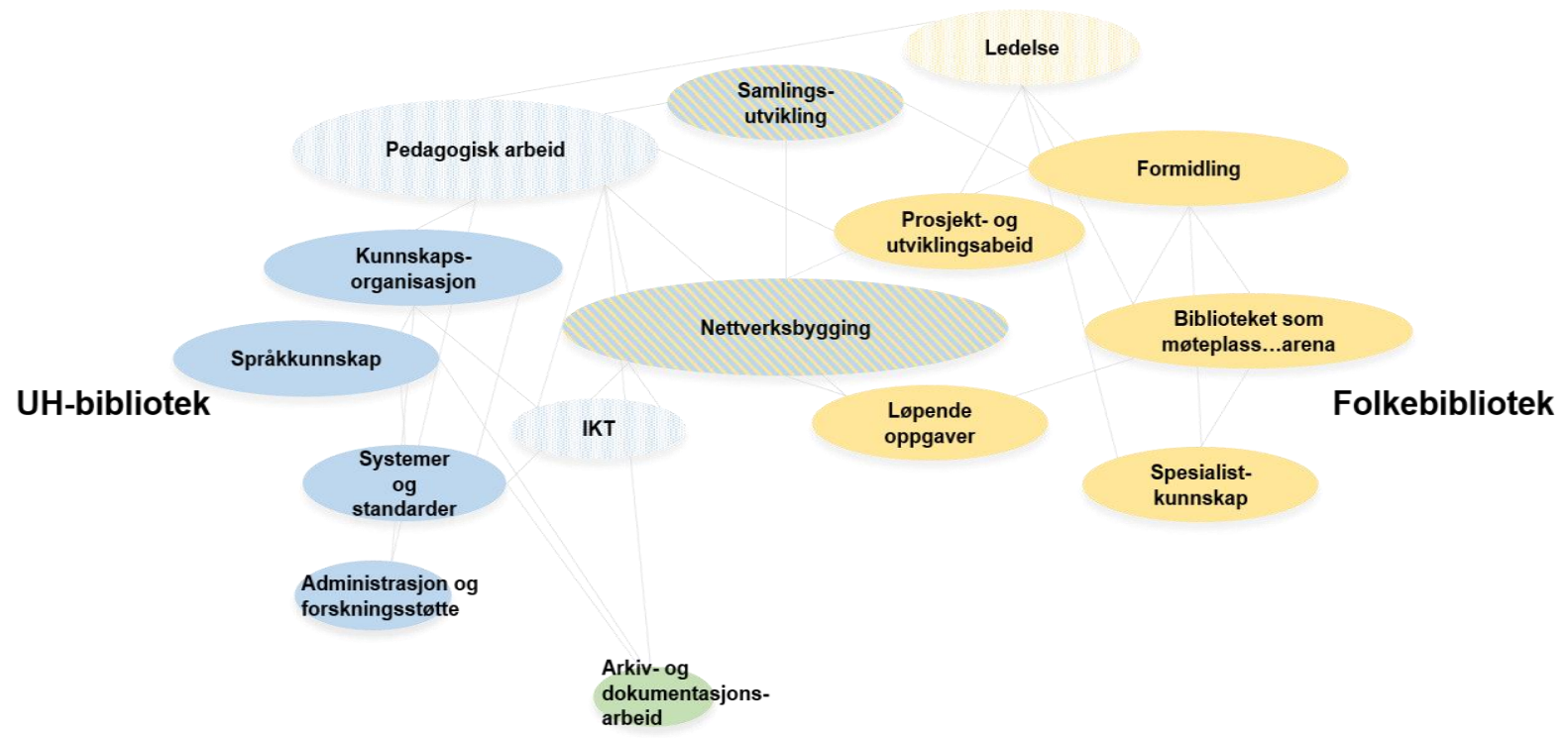

Fagbibliotek/Arkiv

Figur 1. Modell av relasjoner mellom kompetanseområdene (2015-2018).

\section{Endringer fra 2002 til 2015-18}

Datamaterialet fra 2002 er betydelig mindre enn det som er beskrevet over, men stort nok til at det kan indikere noen tydelige tendenser, slik tabell 5 viser. Fra 2002 til 2015 har det foregått en liberalisering av utdanningskrav. I tillegg fremstår kompetanseuttrykkene mer homogene og profesjonsspesifikke.

Kravet om (minimum) bachelor i bibliotek og informasjonsfag er blitt redusert fra 64\% i 2002 til $36 \%$ i dag. Annonsene som åpner for "annen relevant utdanning" har $\varnothing \mathrm{kt}$ fra 11\% i 2002 til 32\% i dag . Krav om spesifisert eller uspesifisert utdanning utenom LIS har steget fra $4 \%$ til $16 \%$ i samme periode. Antall annonser uten eksplisitte utdanningskrav har sunket fra $15 \%$ til $5 \%$.

\begin{tabular}{|c|c|c|c|c|c|}
\hline \multicolumn{3}{|l|}{ Utdanningskrav } & \multicolumn{2}{|l|}{2002} & \multirow{2}{*}{$\begin{array}{l}\text { Endring i } \\
\text { prosentpo } \\
\text { eng til } \\
2015-18\end{array}$} \\
\hline & & & Antall & Prosent & \\
\hline \multirow{4}{*}{$\begin{array}{l}\text { Utdanning innen } \\
\text { bibliotek og } \\
\text { informasjonsfag er } \\
\text { nevnt i utlysningen } \\
(81 \%)\end{array}$} & \multicolumn{2}{|c|}{$\begin{array}{l}\text { Krav om (minimum) bachelor i bibliotek } \\
\text { og informasjonsfag }\end{array}$} & 30 & $64 \%$ & $\nabla 28$ \\
\hline & \multicolumn{2}{|c|}{$\begin{array}{l}\text { Krav om master i bibliotek og } \\
\text { informasjonsfag }\end{array}$} & 0 & $0 \%$ & 0 \\
\hline & \multicolumn{2}{|c|}{$\begin{array}{l}\text { Krav om høyere utdanning på bachelor } \\
\text { eller masternivå med bibliotek og } \\
\text { informasjonsfag i fagkretsen }\end{array}$} & 1 & $2 \%$ & $\Delta 4$ \\
\hline & $\begin{array}{l}\text { Krav om } \\
\text { (minimum) }\end{array}$ & $\begin{array}{l}\text {...annen relevant } \\
\text { høyere utdanning }\end{array}$ & 5 & $11 \%$ & $\boldsymbol{\Delta} 21$ \\
\hline
\end{tabular}




\begin{tabular}{|c|c|c|c|c|c|}
\hline & $\begin{array}{l}\text { bachelor i } \\
\text { bibliotek og } \\
\text { informasjonsfag, } \\
\text { eller... }\end{array}$ & & & & \\
\hline & & $\begin{array}{l}\text {...relevant } \\
\text { realkompetanse }\end{array}$ & 2 & $4 \%$ & $\nabla 3$ \\
\hline & & $\begin{array}{l}\text {...relevant } \\
\text { masterutdanning }\end{array}$ & 0 & $0 \%$ & $\Delta 1$ \\
\hline & $\begin{array}{l}\text { Krav om master i } \\
\text { bibliotek og } \\
\text { informasjonsfag, } \\
\text { eller... }\end{array}$ & $\begin{array}{l}\text {...relevant } \\
\text { masterutdanning }\end{array}$ & 0 & $0 \%$ & $\Delta 1$ \\
\hline Utdanning innen & \multicolumn{2}{|c|}{ Krav om uspesifisert høyere utdanning } & 1 & $2 \%$ & $\Delta 6$ \\
\hline informasjonsfag er & \multicolumn{2}{|c|}{ Krav om spesifisert høyere utdanning } & 1 & $2 \%$ & $\Delta 6$ \\
\hline $\begin{array}{l}\text { ikke nevnt i } \\
\text { utlysningen (19\%) }\end{array}$ & \multicolumn{2}{|c|}{ Ingen utdanningskrav } & 7 & $15 \%$ & $\nabla 10$ \\
\hline \multicolumn{3}{|l|}{ Totalt } & 47 & $100 \%$ & \\
\hline
\end{tabular}

Tabell 5. Utdanningskrav uttrykt i annonsene fra 2002

Vi har også sett på hvilke kompetanseuttrykk som nevnes i annonsene fra 2002. Tabell 6 viser uttrykkene som forekommer i minst fem annonser. Vi har ikke gruppert disse i kompetanseområder eller sett hvor i arbeidsmarkedet de forekommer. Listen viser likevel at kompetansene fra 2002 kan sies å ligge tettere opptil tradisjonelle bibliotekariske oppgaver som databaser, katalogisering og samlingsutvikling. Formidlings- og arrangementskompetanse er knapt nok nevnt i 2002.

\begin{tabular}{|l|c|}
\hline Publikumsbetjening & 18 \\
\hline Løpende oppgaver & 15 \\
\hline Utviklingsarbeid & 11 \\
\hline Digital kompetanse & 11 \\
\hline Samlingsutvikling & 10 \\
\hline Databaser & 9 \\
\hline Katalogisering & 9 \\
\hline Micromarc & 8 \\
\hline Brukeropplæring & 7 \\
\hline Administrativt ansvar & 7 \\
\hline IKT-drift & 6 \\
\hline Registrering av informasjon & 6 \\
\hline Prosjekt- og utviklingsoppgaver & 5 \\
\hline Nettverk lokalt, nasjonalt og internasjonalt & 5 \\
\hline Barne- og ungdomsarbeid & 5 \\
\hline BIBSYS & 5 \\
\hline
\end{tabular}




\begin{tabular}{|l|c|} 
Veiledning & 5 \\
\hline Webteknologier & 5 \\
\hline
\end{tabular}

Tabell 6. Kompetanser og arbeidsoppgaver uttrykt $i$ annonsene 2002.

\section{Diskusjon}

Kompetanser

Kompetanseområdene vi finner i denne undersøkelsen, sammenfaller i stor grad med de arbeidsoppgavene som angis å være de viktigste i kandidatundersøkelsen til Bøyum, Dahl og Pharo (2015). Litteraturformidling scorer høyest i folke-, skole- og fylkesbibliotek i kandidatunders $\varnothing$ kelsen. Formidling er ofte, men ikke alltid, spesifisert som litteraturformidling, og scorer meget høyt også i stillingsannonsene for folke- og skolebibliotek. Samlingsutvikling, som er på henholdsvis andre og tredje plass i kandidatunders $\varnothing$ kelsen, scorer høyt for alle bibliotektyper også i vårt materiale. I kandidatundersøkelsen oppgir respondentene fra fag- og forskningsbibliotekene at opplæring og veiledning er deres viktigste arbeidsoppgave. Disse oppgavene scorer meget høyt også i vårt materiale, og er ofte nevnt sammen med ulike former for forskningsstøtte.

Kompetanseområdet vi har kalt Kunnskapsorganisasjon inkluderer både katalogisering og referansearbeid. Dette kompetanseområdet er sterkt knyttet til UH-bibliotek. I kandidatundersøkelsen er klassifikasjon og indeksering rangert som nummer tre i fag-og forskningsbibliotekene.

I denne undersøkelsen finner vi som nevnt tre nokså utbredte kompetanseuttrykk som forekommer i nær halvparten av annonsene. Disse gjør seg gjeldende i alle institusjonstyper, selv om fordelingen er skjev. Det er også en stor grad av overlapp mellom kompetanseområdene, som altså innebærer at den enkelte annonse etterspør kunnskaper og ferdigheter på tvers av våre kategorier. Dette borger for en "generalist", men kanskje en litt ny type generalist i 2015-18 enn i 2002. Fra generalistkompetanse knyttet til tradisjonelle bibliotekspesifikke fag, flyttes vekten over til generalistkompetanse som i stor grad innbefatter formidling, nettverksbygging og annen utadrettet virksomhet. Ettersom digital kompetanse er det aller mest typiske kompetanseuttrykket, og IKT både er et eget kompetanseområde og et fenomen som inngår på ulike måte i de fleste andre områder, så har sannsynligvis generalistkompetansen også blitt mer "digital".

På den annen side finner vi tydelige tegn på krav om nokså spesialisert kompetanse, som kommer i tillegg til generalistkompetansen. Vi finner dessuten to hovedklynger av kompetanser som ligger langt fra hverandre, og som utfordrer generalist-tradisjonen. Våre funn fra Norge ser dermed ut til å bekrefte Wise, Henninger og Kennan`s (2011) tidligere funn fra Australia om at generalist-forventningene fortsatt finnes i arbeidsmarkedet, men forstått som en basis som ligger under forventninger og krav om mer spesialisert kunnskap. Det at institusjonene i stor grad har åpnet opp for annen relevant utdanning og ofte spesifiserer denne, peker også i denne retningen. Man skal fortsatt utføre tradisjonelle oppgaver i bibliotekene som publikumsbetjening og samlingsutvikling, men bibliotekene ønsker også å videreutvikle sine roller og funksjoner.

I analysen av sitt nyeste materiale viser Kennan et.al. $(2006$, s.33) til en "lack of uniformity":

kompetansekravene fra det australske arbeidsmarkedet dekker et så bredt spekter at det leder til et spørsmål fra forfatterne om hva det egentlig vil si å ha en bibliotek- og informasjonsfaglig kompetanse. I vårt materiale fra 2015-18 ser vi på liknende vis en større bredde og en økning i kravene om mer spesialisert kompetanse enn i annonsene fra 2002. Dette harmonerer med Kennan et al, som finner en $\varnothing$ kende kompleksitet og spesialisering i deres materiale fra 2004 enn i de tidligere tiårene. Tendensen kan leses som en mulig fragmentering av bibliotekarprofesjonen, og gir utdannerne i bibliotekprofesjonen adskillig å tenke på i utformingen av framtidige studietilbud.

\section{Utdanning}

Utdanningen i bibliotek- og informasjonsvitenskap ved OsloMet er på bachelornivå en generalistutdanning basert på fag fra ulike emnegrupper. På masternivå kan studentene velge spesialisering innenfor en av emnegruppene eller ta emner på tvers. Ved utdanningen i Oslo og andre steder har det vært en tilbakevendende 
debatt om hvorvidt man også på bachelornivå skal åpne for en større grad av spesialisering innenfor fagporteføljen, eller om man skal beholde generalistperspektivet og utdanne profesjonsut $\varnothing v e r e$ med kunnskaper fra en unik sammenstilling av fagområder (se for eksempel Audunson, Nordlie \& Spangen, 2003). Internasjonalt har man også debattert hvorvidt LIS-utdanninger bør fokusere på tradisjonelle og praksisnære ferdigheter som katalogisering eller tilpasse seg en mer akademisk og bredere informasjonsvitenskap (Gorman, 2004). Sammenstilling og syntetisering av heterogene kunnskaper er en typisk egenskap for profesjonsyrker. Innenfor profesjonsteorien reiser man derfor spørsmål om hvor de ulike elementene i profesjonens kunnskaper kommer fra, hvor godt disse elementene er integrert og om integrasjon baserer seg på teoretiske eller praktiske synteser (Grimen, 2008). Til disse spørsmålene finnes det som antydet ulike svar og posisjoner både innenfor bibliotekog informasjonsutdanningen og profesjonen.

Vår studie viser at arbeidsoppgavene i arbeidsmarkedet spenner over et svært bredt felt, og at det trengs kunnskaper både fra teknologifag, samfunnsfag og humanistiske fag. Kunnskapene som kreves i de ulike endene av dette feltet, vil derfor variere betydelig. Vi har identifisert noen veletablerte kompetanseområder som eksemplifiserer bredden i feltet. Områdene grupperer seg i to hovedklynger knyttet til henholdsvis UH- og folkebibliotek. Samtidig går mange av kompetanseuttrykkene igjen på tvers av områdene, og vi har noen områder som legger seg ganske midt $\mathrm{i}$ feltet uten sterke bindinger til én bibliotektype. Blant disse er Nettverksbygging og Pedagogisk arbeid. Sett i sammenheng kunne man kanskje hevde at kompetanser knyttet til ulike former for utadrettet virksomhet, og digital kompetanse som nevnes i 124 av annonsene har fått noen praktiske integrerende funksjoner på tvers av kompetanseområdene. På dette området behøves imidlertid videre studier for å kunne si noe mer kvalitativt om disse funksjonene. Utover at de involverte institusjonene og de utlyste stillingene på ulike måter befatter seg med tilgjengeliggjøring av informasjon og kultur, og at det sannsynligvis foreligger et delt verdigrunnlag knyttet til dette oppdraget, er det også vanskelig på bakgrunn av denne studien å identifisere noen teoretiske synteser som binder kompetansene sammen.

Vi så en reduksjon i eksplisitte krav om fagutdanning i bibliotek- og informasjonsfag fra 2002 til 2015-18 -materialet sett under ett. Dette gjaldt som nevnt spesielt bibliotekene i de fire store byene, hvor kun ét krevde bibliotekfaglig utdanning. Materialet viser dermed en liknende tendens, som i den australske undersøkelsen. (Kennan et.al. 2006), der prosentandelen annonser som krevde bibliotekfaglig utdanning sank fra $74 \%$ i 1974 til 33 \% i 2004 (s. 26). Går vi grundigere inn i våre tall fra 2015-18, spør altså 36\% spesifikt etter kandidater med bachelorgrad i bibliotek- og informasjonsvitenskap. Dette tallet har sunket med 28 prosentpoeng fra 2002. Tilsvarende har andelen som åpner opp for «annen relevant utdanning» $\varnothing \mathrm{kt}$ med 21 prosentpoeng over den samme perioden. I UH-sektoren ser vi også en stor $\varnothing$ kning av annonser som etterlyser annen spesifisert eller uspesifisert høyere utdanning. Dette er et tydelig utviklingstrekk.

Abbott's jurisdiksjonsbegrep beskriver som nevnt hvordan profesjoner kan kjempe om monopol over ulike arbeidsoppgaver, og utdanning er innenfor mange profesjoner en måte å skaffe seg dette monopolet på. Man kan for eksempel ikke jobbe som lege uten en godkjent medisinsk utdanning eller som jurist uten juridikum. Selv om "bibliotekar" ikke er en beskyttet tittel, og ikke representerer en yrkesgruppe med formell jurisdiksjon over bestemte arbeidsoppgaver i samfunnet, forstås gjerne yrket som en profesjon på bakgrunn av at mange av yrkesut $ø$ verne deler en utdanning innenfor bibliotek- og informasjonsvitenskap. Profesjonenes jurisdiksjon er imidlertid ikke naturgitt. Vel kjent er profesjonsstriden mellom leger og sykepleiere og mellom sykepleiere og hjelpepleiere. Et konkret eksempel innen helsesektoren i Norge, er striden mellom farmasøyter og leger, hvor farmas $\varnothing$ ytene begir seg inn på legenes område ved å gi andre råd til pasienten om medikamentbruk enn det legene har foreskrevet. Dette går ikke upåaktet hen blant legene (Ali, 2014).

Våre funn kan tyde på at bibliotekarenes jurisdiksjon i bibliotekene er blitt svakere siden 2002, og at det er stor åpenhet i biblioteksektoren for å inkludere kandidater med annen utdanning. Dette gjelder også på områder hvor bibliotekarene selv får kompetanse gjennom egen utdanning, som for eksempel innenfor litteraturformidling og utviklingsoppgaver. Om denne trenden til å ville åpne opp for andre profesjoner skyldes behov for en mer spisset kompetanse på slike områder enn det en generalistutdanning gir, eller om det skyldes 
usikkerhet på egne kunnskaper og ferdigheter, er et spørsmål det kunne være interessant å undersøke. Det ville også være interessant å sammenligne tendensen til å utlyse stillinger uten spesifikke utdanningskrav med tendenser innenfor andre profesjoner.

Abbott har hevdet om bibliotekarprofesjonen at den med tiden vil bli mer sentralisert, og med det konsentreres om en mindre elite som besitter kjernekompetanse og bruker den til "indre arbeid" med samlingen og med spesialiserte systemer for gjenfinning, mens en større og mer perifer gruppe betjener publikum (Abbott, 1998, s. 440). Våre funn peker i retning av at de tradisjonelle bibliotekaroppgavene fortsatt etterspørres, og særlig i UH-bibliotek, for eksempel uttrykt gjennom kompetanseområdene vi har kalt Kunnskapsorganisasjon og Systemer og standarder. Dette er sannsynligvis områder hvor bibliotekarutdanning gir en mer eksklusiv kompetanse enn den som tilbys gjennom andre studier, og her kreves det da også oftere bibliotekfaglig utdanning enn i andre områder. Vårt materiale bekrefter dermed til en viss grad Abbotts poeng om at de sentrale kjernekompetansene sentraliseres i deler av profesjonsfeltet.

Vi ser imidlertid også at publikumskontakten har blitt en spesialisert del av det bibliotekfaglige arbeidsmarkedet, noe som kommer tydelig til uttrykk gjennom områdene Formidling og Biblioteket som møteplass og debattarena. Her åpnes det i større grad opp for annen relevant bakgrunn. Abbotts påstand om at publikumskontakt er et perifert kompetanseområde i den bibliotekfaglige profesjon, ser dermed ikke ut til å stemme. Våre funn viser tvert imot at kompetanser knyttet til dette har blitt en vesentlig inngangsbillett til særlig stillinger $\mathrm{i}$ folkebiblioteksektoren. I en dansk kontekst anvender Jochumsen (2017, s. 18) betegnelsen biblioteksformidler i stedet for bibliotekar. Det begrunnes nettopp med at det i dag etterspørres nye kompetanser som supplerer de tradisjonelle, og at en slik utvidelse av stillingsbetegnelsen vil fange opp dem som ikke har bibliotekarutdanning. Jochumsen peker i tillegg på at det i en dansk kontekst var slik at de som jobbet i bibliotek tidligere i større grad hadde sin utdannelse fra Danmarks biblioteksskole.

Bibliotekarprofesjonen ser ut til å bekrefte Susskind og Susskind hypotese om sterk endring. De peker på teknologi som den viktigste endringsdriveren. Teknologien gjør det langt på vei mulig for bibliotekbrukere å løse tidligere spesialistoppgaver selv. Dette innskrenker bibliotekarprofesjonens arbeidsfelt. Samtidig ser vi at både folke- og UH-bibliotek utvider sitt virkeområde. De tilbyr flere nye tjenester, og legger vekt på å være et sted for opplevelser eller møter. Denne utadrettede publikumskontakt-siden ved virksomheten ser ikke profesjonen ut til å ha gjort til sin egen, men åpnet for spesialisert personale med andre typer kompetanse enn bibliotekfag.

Et hovedfunn i vår undersøkelse er at den eksklusive kompetansen bibliotekarene har fått gjennom sine studier, ser ut til å marginaliseres i folkebibliotekene. Arbeidsmarkedet uttrykker imidlertid nokså tydelig at det er spesialiserte kompetanser og arbeidsoppgaver som erstatter disse. Det ser dermed ikke ut til at mengden oppgaver i folkebiblioteket er automatisert bort, slik Susskind og Susskind hevder kan skje, men at oppgavene har forandret seg. Disse "nye" kompetansene knyttet til formidling og andre former for utadrettet virksomhet, er ikke på samme måte bundet til en eksklusiv utdanning. Dette gir de tradisjonelle bibliotekarutdanningene en ny konkurransesituasjon.

\section{Begrensninger}

Stillingsannonser tilhører en tekstsjanger med betydelig gjenbruk av språklig konvensjoner, og er ikke nødvendigvis helt presise uttrykk for de kvalifikasjonene og egenskapene arbeidsgiver ser etter og har behov for. Når annonsematerialet fra 2015-18 er langt mer ordrikt enn utvalget fra 2002, sier dette også noe om en generell utvikling innenfor stillingsannonseutforming, der det nå for eksempel ofte legges inn mange ønskede personlige egenskaper, noe som vi også finner i en av de australske undersøkelsene (Kennan et.al. 2006). Det er heller ikke sikkert at personene som tilsettes er de blant søkerne som best fyller den faglige profilen som annonsene etterspør. Annonsene representerer likevel tilgjengelige beskrivelser av hva arbeidsgiver ønsker seg, og er det mest informative materialet vi har til en kvantitativ unders $\varnothing$ kelse av kompetansebehov. For å få et mer komplett bilde av hva bibliotekene virkelig ønsker seg og har behov for, bør studien suppleres med intervjuer med noen av de som har foretatt tilsettingene, samt informasjon om de som fikk stillingene. 


\section{Konklusjoner}

Hovedformålet med vår undersøkelse var å kartlegge kompetansene arbeidsmarkedet etterspør. Kompetansebehovene som kommer til uttrykk i materialet vi har unders $\varnothing k t$, viser et stort spenn. Vi finner to hovedområder knyttet til henholdsvis folke- og UH-bibliotek. Disse områdene etterspør til dels ulik kompetanse. Folkebibliotekene legger stor vekt på kunnskaper om, og ferdigheter i formidling. UH-bibliotekene etterspør pedagogisk og kunnskapsorganisatorisk kompetanse.

Sammenlignet med materialet fra 2002 finner vi først og fremst at kravet til formell bibliotek- og informasjonsfaglig utdanning er redusert, samtidig som det i større grad åpnes opp for andre typer relevant utdanning. Dette gjelder i alle typer bibliotek. Vi ser også en større etterspørsel etter kompetanser knyttet til utadrettede arbeidsoppgaver som formidling, og det er overveiende på dette området bibliotekene åpner opp for alternativ utdanningsbakgrunn.

Det bibliotekfaglige profesjonsfeltets reduserte krav til fagutdanning i bibliotek- og informasjonsvitenskap, og åpningen mot andre utdanninger og spesialistkompetanser, kan se ut til å trekke i retning av Susskind og Susskinds framtidsvyer om profesjonenes forvitring. Det er imidlertid ikke bare den teknologiske utviklingen som trekker i den retningen, men vel så mye bibliotekenes ønske om spesialistkompetanse på mange ulike felt. At bibliotekarprofesjonen ligger på sotteseng, kan vi derimot ikke lese ut av vårt materiale. Selv om fagfeltet åpner opp for andre fagutdanninger enn den klassiske bibliotekarutdannelsen, er etterspørselen etter en bachelorgrad i bibliotek- og informasjonsvitenskap vedvarende høy, og $81 \%$ av annonsene nevner faktisk denne utdannelsen. Dette gjelder spesielt fagbibliotek og mellomstore og mindre folkebibliotek. Disse institusjonstypene ser stadig ut til å ha behov for generalistkompetanse i sentrale bibliotek- og informasjonsfaglige emner.

En prøvestein på profesjonens levedyktighet vil være om profesjonsutdanningen og institusjonene som ansetter våre kandidater leverer den kunnskapen og yter de tjenestene som mennesker i det seinmoderne samfunnet har bruk for. I denne sammenhengen mener vi at Jan Nolins fjerde tilnærming til studiet av profesjoner er viktig. I stedet for å studere profesjonene kun med et kritisk utenfrablikk, bør forskerne samarbeide med profesjonsut $\varnothing$ verne og: "...contribute by analysing and discussing the way in which educational programs can be opened up and the way in which the collaboration between academia and professional can be intensified." $(2008$, s. 41).

Denne unders $\varnothing$ kelsen, og videre forskning om hvem som faktisk ansettes i dette profesjonsfaglige feltet, vil gi et grunnlag for videre diskusjon av bibliotek- og informasjonsstudienes innhold og oppbygning.

\section{Referanser}

Abbott, A. (1998). Professionalism and the future of librarianship. Library Trends, 46(3), 430-443.

Abbott, A. (1988). The System of Professions: An Essay on the Division of Expert Labor. Chicago: The University of Chicago Press.

Ali, M. A. (2014, 3. november). Apotekfarmas øyter ingen trussel for legene. Dagens medisin. Hentet fra https://www.dagensmedisin.no/artikler/2014/11/03/apotekfarmasoyter-ingen-trussel-for-legene/

Audunson, R., Nordlie, R., Spangen, I. C. (2003). The complete librarian - an outdated species? Lis between profession and discipline. New Library World, 104(6), 195-202.

Bibliotekloven. (1985). Lov om folkebibliotek. Hentet fra https://lovdata.no/dokument/NL/lov/1985-12-20-108

Bøyum, I., Dahl, T.A. og Pharo, N. (2015). Bibliotekarer bli ved din lest. I R. Audunson (Red.), Samle, formidle, dele (s. 91-106). Oslo: ABM-Media. 
Choi, Y., \& Rasmussen, E. (2009). What qualifications and skills are important for digital librarian positions in academic libraries? A job advertisement analysis. The Journal of Academic Librarianship, 35(5), 457-467.

Dahl, T.A. \& Tallerås, K. (2011). Hva gjør de videreutdannede bibliotekarene? I R. Audunson (Red.), Krysspeilinger: Perspektiver på bibliotek-og informasjonsfag (s. 165-182). Oslo: ABM-Media.

Fauske, H. (2008). Profesjonsforskningens faser og stridsspørsmål. I A. Molander \& L. I. Terum (Red.), Profesjonsstudier (s. 31-53). Oslo: Universitetsforlaget.

Gorman, M. (2004). Whither library education? New Library World, 105(9-10).

Grimen, H. (2008). Profesjon og kunnskap. I A. Molander \& L. I. Terum (Red.), Profesjonsstudier (s. 71-85). Oslo: Universitetsforlaget.

Hansen, N. J. (2017). Biblioteket gennem 100 år - innhold, rammer og relasjoner. I C. Laskie (Red.), Biblioteksdikdaktik (s. 49-82). København: Hans Reitzels forl.

Illeris, K. (2011). Kompetance: Hvad Hvorfor Hvordan. Fredriksberg: SL-forl.

Jochumsen, H. (2017). Biblioteket gennem 100 år - innhold, rammer og relasjoner. I C. Laskie (Red.), Biblioteksdikdaktik (s. 17-46). København: Hans Reitzels forl.

Jørgensen, P. S. (1999). Hvad er kompetence? Og hvorfor er det nødvendigt med et nyt begreb? Uddannelse, 9(32), 4-13.

Kennan, M. A., Willard, P., \& Wilson, C. S. (2006). What Do They Want?: A Study of Changing Employer Expectations of Information Professionals. Australian Academic \& Research Libraries, 37(1), 17-37.

Kim, J., Warga, E., \& Moen, W. (2013). Competencies Required for Digital Curation: An Analysis of Job Advertisements. International Journal of Digital Curation, 8(1), 66-83.

Kultur- og forskningsdepartementet. (2004). Kultur for læring. (melding til Stortinget nr. 30 2003-2004). http://hb.diva-portal.org/smash/get/diva2:883755/FULLTEXT01.pdf

Miller, M. M., \& Horan, M. (2017). Evolving roles of preservation professionals: Trends in position announcements from 2004 to 2015. Library Resources \& Technical Services, 61(4), 183-197.

Nolin, J. (2008). In search of a new theory of professions. Science for the professions, report no. 4. University of Borås. http://hb.diva-portal.org/smash/get/diva2:883755/FULLTEXT01.pdf

Park, J., \& Lu, C. (2009). Metadata Professionals: Roles and competencies as reflected in job announcements, 2003-2006. Cataloging \& Classification Quarterly, 47(2), 145-160.

Séguinot, C. (2007). Translation and the changing profession: A cross-diciplinary perspective. TTR: Traduction, terminologie, redaction, 20(1), 171-191.

Susskind, D. \& Susskind, R. (2015). The future of the professions: how technology will transform the work of human experts. Oxford: Oxford University Press. 
Wilkinson, A., Hislop, D. \& Coupland, C. (Red.). (2016). Perspectives on contemporary Professional Work: Challenges and Experiences. Cheltenham: Elgar.

Wise, S., Henninger, M., \& Kennan, M. A. (2011). Changing Trends In LIS Job Advertisements. Australian Academic \& Research Libraries, 42(4), 26 